\title{
New records and estimation of the potential distribution of the Stump-Tailed Porcupine Coendou rufescens
}

\author{
Carlos Narváez-Romero' ${ }^{1}$ Carolina Reyes-Puig ${ }^{2}$, DarWin Valle ${ }^{3}$, and Jorge Brito $4,5 *$
}

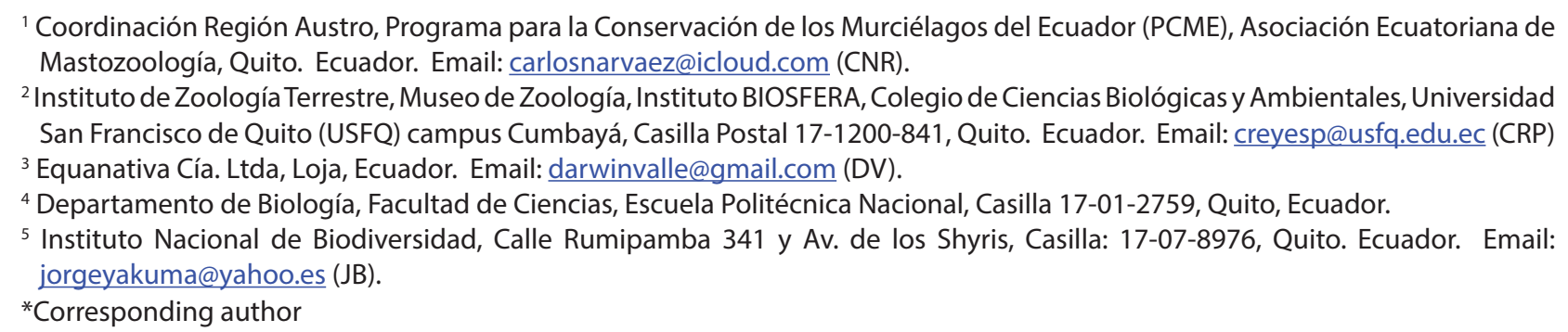

The stump-tailed porcupine (Coendou rufescens) is a medium-sized species that inhabits subtropical, temperate and High-Andean forests of the northern Andes, at 800 to 3,650 m asl. This species is characterized by a short non-prehensile tail and a distinctive reddish color. Here, we report new localities for Coendou rufescens in Ecuador based on direct field sightings and the revision of mammal collections. In addition, we conducted a review of literature records of $C$. rufescens throughout its distribution range. A total of 52 georeferenced records were modeled for the potential distribution at the regional level (Colombia, Ecuador, and Peru) based on 19 bioclimatic variables. Finally, we overlaid the layers of vegetation remnants and state protected areas. We report 10 new localities for Coendou rufescens in Ecuador; these records are concentrated to southern Ecuador between 1,120 to 4,387 masl. Fifty two records found that the bioclimatic variables Temperature Seasonality (BIO4) and Minimum Temperature of the Coldest Month (BIO6) associated with the type of habitat made the greatest significant contribution to the distribution model of $C$. rufescens. The suitable habitat for the species spans across $\sim 448,820 \mathrm{~km}^{2}$, with $50.4 \%$ in Colombia. These findings indicate that the locality Camino del Inca in Sangay National Park, at 4,387 m asl, is considered the highest-elevation record for C. rufescens and the family Erethizontidae. Colombia and Peru include the highest proportion of potential habitat across its range (40.2 \% and $32.7 \%)$ based on remnant vegetation; however, Ecuador maintains the largest proportion of the porcupine distribution within protected areas (35.5\%), with a larger extent of landscape connectivity, essential for the conservation of $C$. rufescens.

El puerco espín de cola corta (Coendou rufescens) es una especie de tamaño mediano que habita los bosques Subtropicales, Templados y Alto-Andinos de los Andes norte, entre los 800 a 3,650 m de elevación. Esta especie se caracteriza principalmente por presentar una cola corta y no prensil, además de su peculiar coloración rojiza. Se reportan nuevas localidades para Coendou rufescens sobre la base de avistamientos directos en campo y revisión de colecciones mastozoológicas. Adicionalmente se realizó una revisión de los registros bibliográficos de C. rufescens a lo largo de su distribución geográfica. Con un total de 52 registros recopilados y georefenciados, se modeló la distribución potencial a escala regional (Colombia, Ecuador y Perú) utilizando 19 variables bioclimáticas seleccionadas por su nivel de correlación. Finalmente, se superpusieron las capas de vegetación remanente y áreas protegidas estatales. Se adicionan 10 localidades para Coendou rufescens en Ecuador, los registros se concentran en el sur del país en un rango altitudinal entre 1,120 a 4,387 m. Con base a los 52 registros se determinó que las variables bioclimáticas que contribuyen más significativamente al modelo de distribución predictiva son BIO4: Temperatura estacional y BIO6: Temperatura mínima del mes más frío, las cuales están asociadas al tipo de hábitat. Se determinó que el hábitat idóneo para la especie es de $\sim 448,820 \mathrm{~km}^{2}$, donde el $50.4 \%$ de la distribución potencial se concentra en Colombia. La localidad del Camino del Inca en el Parque Nacional Sangay, ubicado a 4,387 m es el registro de mayor elevación para C. rufescens y la familia Erethizontidae. Colombia y Perú contienen la proporción más alta de hábitat adecuado para la especie (40.2 y $32.7 \%)$ con base en la vegetación remanente; no obstante, Ecuador mantiene la mayor proporción de la distribución dentro de áreas protegidas (35.5\%), por ende, presentaría mayor conectividad de paisaje, lo cual es esencial para la conservación de C. rufescens.

Key words: altitudinal range; distribution model; mammals; protected area; vegetation remnants

๑ 2018 Asociación Mexicana de Mastozoología, www.mastozoologiamexicana.org

\section{Introduction}

The genus Coendou Lacépède, 1799 (Rodentia: Erethizontidae), distributed only in America, groups together 13 species that live in tropical, subtropical and temperate areas in wet and dry forests, from sea level up to 3,650 masl (Voss et al. 2013; Voss 2015; Brito and Ojala-Barbour 2016). The stump-tailed porcupine Coendou rufescens Gray, 1865 is distributed in the Andes of Colombia, Ecuador and northwestern Peru (Alberico et al. 1999; Voss 2011, 2015; Tirira 2016; Brito and Ojala-Barbour 2016; More and Crespo 2016; Romero et al. 2018). An unusual record from northern Bolivia has been recently reported, representing a biogeographical enigma that suggests that some individuals of this species moved to this area (Voss 2011). 
Coendou rufescens is characterized mainly by a short non-prehensile tail, unlike other long-tailed porcupines, in addition to its distinctive reddish coloration (Voss 2015). Although the ecological information available for $C$. rufescens is rather limited, it is considered as a species that inhabits only mature and well-preserved forests (Tirira 2017). Some point observations in the Sangay National Park in Ecuador have served to characterize the species as either solitary or gregarious (1 to 4 individuals), diurnal and nocturnal (Brito and Ojala-Barbour 2016). Incidental records have documented that the stump-tailed porcupine is preyed upon by pumas (Tirira 2016) and ocelots (Sanchez et al. 2008).

A predictive distribution model can be used to locate suitable or potential habitats outside of the known range of a given species (e. g., Morueta-Holme et al. 2010; Chatterjee et al. 2012; Ortega-Andrade et al. 2015). Some potentialdistribution correlation models (Braunisch et al. 2008; Peterson et al. 2011) use information on the current distribution of the species and assume that the habitat where records are located represents the ideal habitat for the species. However, the distribution of many vertebrates (especially those threatened) has shrunk, and thus these species could be considered as refugee species, that is to say, limited to survive in suboptimal habitats due to anthropogenic pressures (Kerley et al. 2012).

One of the methods frequently used for modeling the potential distribution is maximum entropy modeling (e. g., Phillips et al. 2006; Phillips and Dudik 2008; Elith et al. 2011; Renner et al. 2013; Nuchel et al. 2018), which has proved to be useful for establishing high-diversity, high-endemism and conservation areas for vertebrates in Neotropical regions (Cuesta et al. 2017; Reyes-Puig et al. 2017). This method is often better than traditional statistical approaches and other species-distribution modeling methods (Elith et al. 2006; Phillips et al. 2006). However, several authors suggest using a consensus of models to reduce the uncertainty of predictions derived from individual models (e. g., Marmion et al. 2009; Qiao et al. 2015; Zhu and Peterson 2017).

This work reports 10 new localities for Coendou rufescens in Ecuador. A potential distribution model was developed for Colombia, Ecuador and Peru using the new localities, those available in the literature, and those associated to museum vouchers. In addition, the geographical layers of remnant vegetation in the three countries were overlaid and the proportion of each within the potential distribution range was calculated. The information on the extension of the distribution range may be valuable for further taxonomic, phylogenetic and ecological studies, while contributing relevant data for the protection of this poorly known species.

\section{Materials and Methods}

Records of living and road killed individuals were obtained through direct field observations during various faunal surveys conducted as part of environmental studies for mining and power companies between years 2007 and 2017.
In addition, two specimens of $C$. rufescens (MEPN 3260 and 10433) deposited in the mammal collection of the Escuela Politécnica Nacional (MEPN), Quito-Ecuador, were also examined. Each encounter was georeferenced and photographed, recording the behavior of each living specimen. In addition, informal interviews were carried out to residents living in the study area to determine the extent of the local knowledge about the species.

Potential Distribution Model. In order to estimate the potential distribution of $C$. rufescens, records were obtained from the published literature (Gray, 1865; Williams 2008; Ramírez-Chávez et al. 2008; Tirira and Boada 2009; Fernández de Cordoba-Torres and Nivelo 2016; More and Crespo 2016; Brito and Ojala-Barbour 2016; Romero et al. 2018), along with the new records from this study (Appendix 1). Presence coordinates were transformed to the decimal degree coordinate system, Datum WGS84 and Universal Transverse Mercator projection (UTM), zones $17 \mathrm{~S}$ and $18 \mathrm{~S}$. Duplicate coordinates and those that were less than $2 \mathrm{~km}$ away from each other were discarded, thus avoiding oversampling presence records while preserving the independence between localities and bioclimatic variables.

The potential-distribution exploratory model was developed based on the 19 bioclimatic variables of WorldClim 191.4 (http://www.worldclim.org; Table 1), which are geo-environmental layers derived from monthly temperature and precipitation data with a resolution of ca. 1 $\mathrm{km}^{2}$ (Hijmans et al. 2005). The model was developed with the software MaxEnt v3.3.3 (Phillips et al. 2006) based on the maximum entropy principle and the convergence of environmental variables covering an area of suitable habi-

Table 1. Contribution of 19 bioclimatic variables to the predictive model of Coendou rufescens.

\begin{tabular}{lll}
\hline Code & Contribution & Variable \\
\hline $\mathrm{BIO} 4$ & 28.15 & Seasonal temperature \\
$\mathrm{BIO} 6$ & 16.89 & Minimum temperature of the coldest month \\
$\mathrm{BIO} 18$ & 15.04 & Precipitation of the warmest annual quarter \\
$\mathrm{BIO} 8$ & 10.94 & Mean temperature of the wettest annual quarter \\
$\mathrm{BIO} 19$ & 4.72 & Precipitation of the coldest annual quarter \\
$\mathrm{BIO} 11$ & 4.64 & Mean temperature of the coldest annual quarter \\
$\mathrm{BIO3}$ & 3.45 & Isothermality \\
$\mathrm{BIO} 10$ & 3.22 & Mean temperature of the warmest annual quarter \\
$\mathrm{BIO} 1$ & 2.49 & Mean annual temperature \\
$\mathrm{BIO} 14$ & 2.38 & Precipitation of the driest month \\
$\mathrm{BIO} 13$ & 1.89 & Precipitation of the wettest month \\
$\mathrm{BIO} 7$ & 1.64 & Annual temperature range (BIO5-BIO6) \\
$\mathrm{BIO} 16$ & 1.32 & Precipitation of the wettest annual quarter \\
$\mathrm{BIO} 17$ & 1.25 & Precipitation of the drieest annual quarter \\
$\mathrm{BIO} 15$ & 0.52 & Seasonal precipitation \\
$\mathrm{BIO} 12$ & 0.45 & Annual precipitation \\
$\mathrm{BIO} 2$ & 0.45 & $\begin{array}{l}\text { Diurnal mean range (monthly average (max temp-min } \\
\text { temp) }\end{array}$ \\
\hline $\mathrm{BIO}$ & 0.29 & Maximum temperature of the warmest month \\
& & Mean temperature of the driest annual quarter \\
\hline
\end{tabular}


tat (Elith et al. 2006; Phillips et al. 2006; Ortega-Andrade et al. 2015). The maximum entropy model uses a confusion matrix that combines the predicted presence/absence with pseudo-absence and true-presence data, producing commission and omission rates. In addition, the probability distributions estimated by the software should be consistent with the known environmental conditions of the species (Peterson et al. 2011).

A total of 52 validated presence records and the 19 bioclimatic variables were entered in MaxEnt. Fifty replicates were run with a Jackknife test to measure the percent contribution of the variables to the model (Phillips et al. 2006; Lizcaino et al. 2015; Ortega-Andrade et al. 2015). A correlation matrix was elaborated with the key variables; highly correlated variables were eliminated by means of a correlation chart $(r>0.8)$. To build the model, we established a convergence threshold of 0.00001 , a maximum of 1000 interactions, and a regularization parameter of 1 . The model was tested and calibrated with 50 additional replicates using non-correlated climatic variables; data were split into $25 \%$ as test and $75 \%$ as training data (MenendezGuerrero and Graham 2013). The "Equal training sensitivity and specificity" cohort threshold was selected, as it reflects a lower omission rate (Liu et al. 2005).

The predictive capacity of the model was evaluated by ROC (Receiver Operating Characteristic) curves and AUC (Area under the Curve) curves (Hanley and Mc Neil 1982; Lobo et al. 2008). In addition, we used the partial area under the ROC curve test (Lobo et al. 2008), thereby avoiding the improper calculation of the weight in AUC commission and omission rates (Lobo et al. 2008; Peterson et al. 2008). Partial AUCs were calculated using the ToolBox developed by Osorio-Olvera (2018). The statistical significance of AUC was tested by bootstrapping and comparisons vs. null hypotheses (i. e., $\mathrm{Ho}=$ difference between model-predicted AUC and random AUC is $\leq 0$ ). We used $50 \%$ of presence data at random for the resampling, with 500 iterations. Significance was evaluated using the calculated AUC values and the values of pseudo-replicates following the proposal of Peterson et al. (2008). All distribution, normality and correlation statistical analyzes of variables were run in the statistical program $\mathrm{R}$ ( $\mathrm{R}$ Core Team 2016). Once the model was calibrated, a final model was constructed with $100 \%$ of the presence data and non-correlated bioclimatic variables in order to obtain the distribution predictive model.

The total potential distribution area was calculated for Colombia, Ecuador and Peru (Datum WGS84 and Universal Transverse Mercator (UTM) projection, zones 175 and 18S). In addition, the layers of remnant vegetation (i. e., plant cover of natural ecosystems) and protected areas for the three countries were overlaid to assess the reduction in the distribution of $C$. rufescens in non-protected areas with no vegetation cover. Maps and calculations of geographic layers were elaborated in ArcMap 10.5.1 (ESRI 2017). The layers of remnant vegetation for Ecuador were obtained from the Sistema Nacional de Información (National Information
System) website (SIN 2017); for Colombia, from the Sistema de Información Ambiental de Colombia (Environmental Information System, SIAC 2017); and for Peru, from the Ministry of the Environment's official website (MINAM 2017).

\section{Results}

New localities. In addition to the Ecuadorian localities previously reported in the literature (Appendix 1), the following are the new localities where the species has been spotted.

1) Road in the vicinity of the Chaguarpamba, province of Loja: The record corresponds to a road killed individual (Figure 1a) photographed on 28 June 2007. The area is a secondary forest (Figure 2a) in a piedmont deciduous forest ecosystem, foothills of the Western Cordillera, southern subregion (Cerón et al. 1999), subtropical western zoogeographical area (Albuja et al. 2012).

2) Quilanga, province of Loja: Individual kept as a pet, photographed (Figure 1b) on 23 June 2011. This specimen was captured in a forest with secondary vegetation adjacent to agricultural land (Figure 2b), montane cloud forest ecosystem, southern sector of the Western Cordillera, southern subregion (Valencia et al. 1999), Temperate zoogeographical area (Albuja et al. 2012).

3) Olmedo, province of Loja: Individual photographed (Figure 1c) on 18 February 2012. The area corresponds to an agricultural area (Figure 2c) located in a piedmont decid-

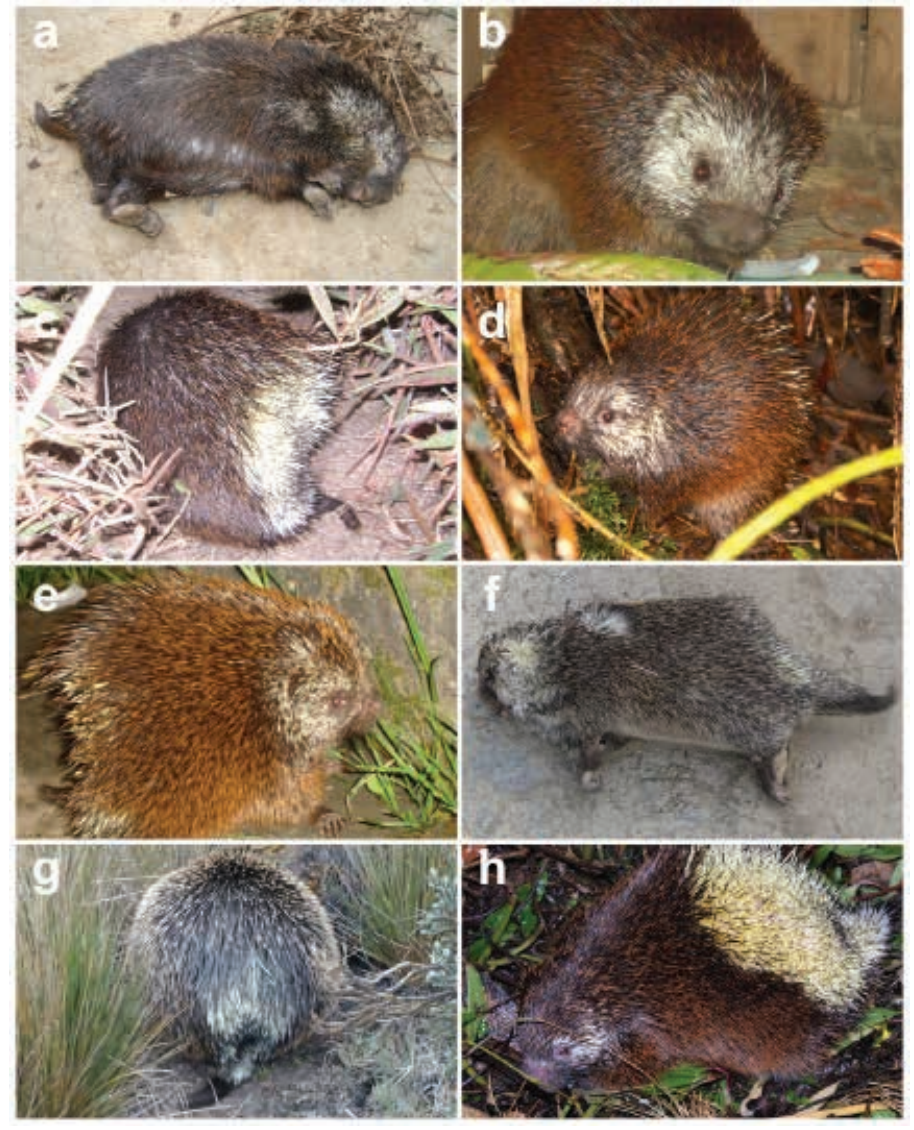

Figure 1. New records of Coendou rufescens in Ecuador: $a=$ Road in the vicinity of Chaguarpamba, $\mathrm{b}=$ Quilanga, $\mathrm{c}=$ Olmedo, $\mathrm{d}=$ vicinity of the Villonaco Wind Project, $\mathrm{e}=$ Barrio Zamora Huayco, $f=$ Vicinity of Gonzanama, $G=$ Camino del Inca, and h $=5 \mathrm{~km}$ of Saraguro. a-f and $\mathrm{h}=$ province of Loja; $\mathrm{h}=$ province of Chimborazo. 


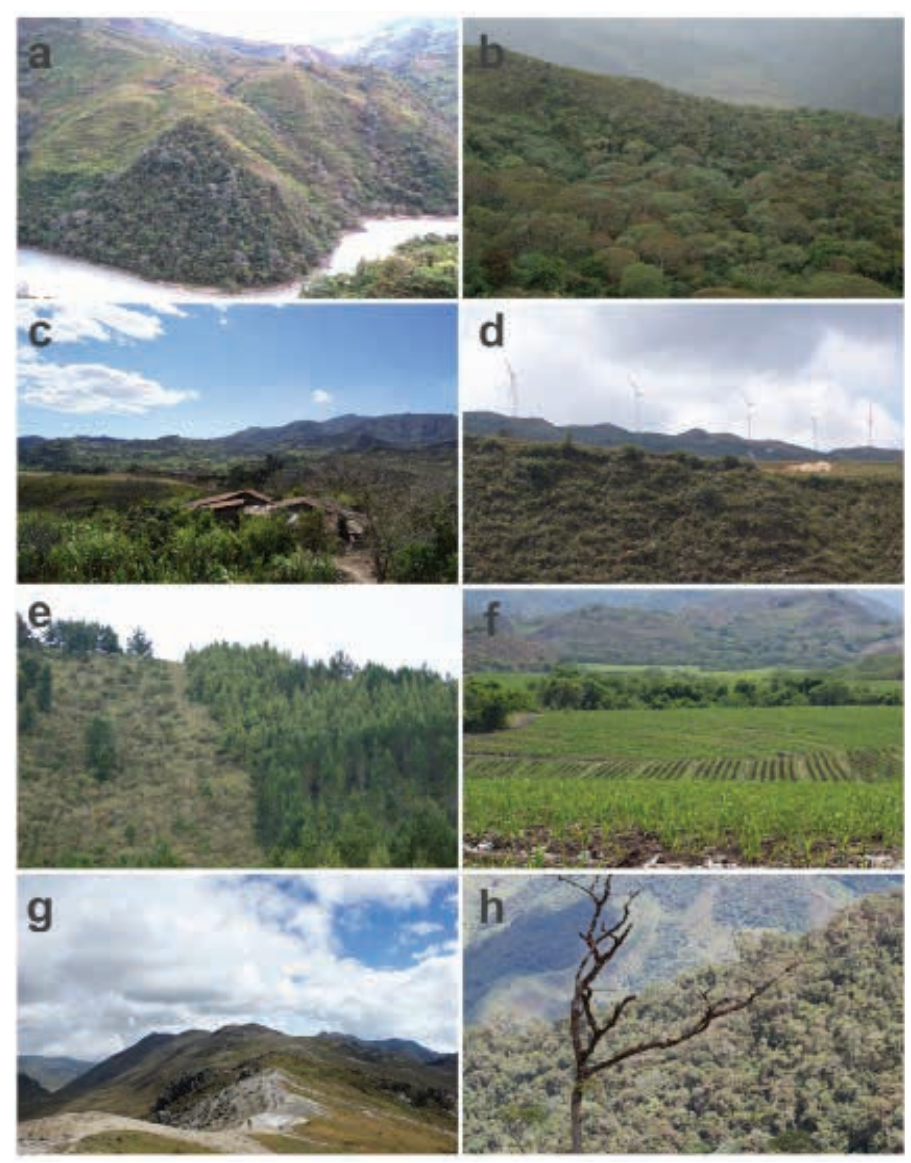

Figure 2. Localities of new records of Coendou rufescens in Ecuador: $a=$ Road in the vicinity of Chaguarpamba, $b=$ Quilanga, $c=$ Olmedo, $d=$ Vicinity of the Villonaco Wind Project, $\mathrm{e}=$ Barrio Zamora Huayco, $\mathrm{f}=$ Vicinity of Gonzanama, $\mathrm{g}=$ Camino del Inca, and $\mathrm{h}$ $=5 \mathrm{~km}$ of Saraguro. a-f and $\mathrm{h}=$ province of Loja; $\mathrm{h}=$ province of Chimborazo.

uous forest ecosystem, foothills of the Western Cordillera, southern subregion (Cerón et al. 1999), subtropical western zoogeographical area (Albuja et al. 2012).

4) Vicinity of the Villonaco Wind Project (Figure 1d), Sucre, province of Loja: Individual photographed on 17 March 2012. The site of the finding corresponds to a rural zone with secondary vegetation and agricultural fields (Figure 2 d) pertaining to a mountain cloud forest, southern sector of the Western Cordillera, southern subregion (Valencia et al. 1999), western Andean high zoogeographical area (Albuja et al. 2012).

5) Zamora Huayco neighborhood in El Sagrario, province of Loja: The record corresponds to an individual (Figure 1e) photographed on 7 September 2012. This was observed in a planted conifer forest (Pinus sylvestris) adjacent to the boundary of the Podocarpus National Park (Figure 2e), montane cloud forest ecosystem, southern sector of the Western Cordillera, southern subregion (Valencia et al. 1999), Temperate zoogeographical area (Albuja et al. 2012).

6) Vicinity of the Gonzanamá, province of Loja: Roadkilled individual photographed on 28 September 2012 (Figure 1f). The area corresponds to an agricultural zone with small remnant patches of native vegetation (Figure $2 \mathrm{f}$ ) pertaining to a mountain cloud forest, southern sector of the Western Cordillera, southern subregion (Valencia et al.
1999), Temperate zoogeographical area (Albuja et al. 2012).

7) Inner zone of the Sangay National Park, province of Morona Santiago: Individual (Figure 1g) photographed on 12 June 2015 in a high Andean moorland in the Camino del Inca sector (Figure 2g). Andean High zoogeographical area (Albuja et al. 2012).

8) $5 \mathrm{~km}$ from Saraguro, province of Loja: Specimen (Figure 1h) photographed on 17 June 2017 in the Huashapamba forest, in an area between shrub vegetation and a pasture located in the western part crossed by the PanAmerican Highway. The area is located inside a protected natural forest (Figure 2h) pertaining to a mountain cloud forest, southern sector of the Western Cordillera, southern subregion (Valencia et al. 1999), Andean High zoogeographical area (Albuja et al. 2012).

9) El Tuni, province of Azuay: MEPN 10433.

10) San Francisco Scientific Station, province of Zamora Chinchipe: MEPN 3260.

The individuals observed and photographed displayed morphological traits consistent with the description for the species (Voss 2015), namely short, blackish, non-prehensile tail measuring about $40 \%$ of the head-body length. Chin, throat and abdomen of pale brown color.

Potential Distribution. An AUC of 0.969 ( $\mathrm{min}=0.945, \max$ $=0.98, \sigma=0.007, \mathrm{n}=50)$ and a AUC ratio of $1.89 \pm 0.04(P<$ 0.05 ) were obtained. Fourteen variables with a significant contribution to the model were identified (Table 1); however, variables $\mathrm{BIO}$, $\mathrm{BIO} 3, \mathrm{BIO}$, $\mathrm{BIO}$, $\mathrm{BIO} 10, \mathrm{BIO} 11, \mathrm{BIO} 13$ $\mathrm{BIO} 16$ and $\mathrm{BIO} 17$ were eliminated for being highly correlated (Figure 3). Five non-correlated bioclimatic variables made a significant contribution to the model; seasonal temperature (BIO4) and minimum temperature of the coldest month (BIO6) accounted for $82.7 \%$, whereas precipitation of the fourth warmer quarter (BIO18), precipitation of

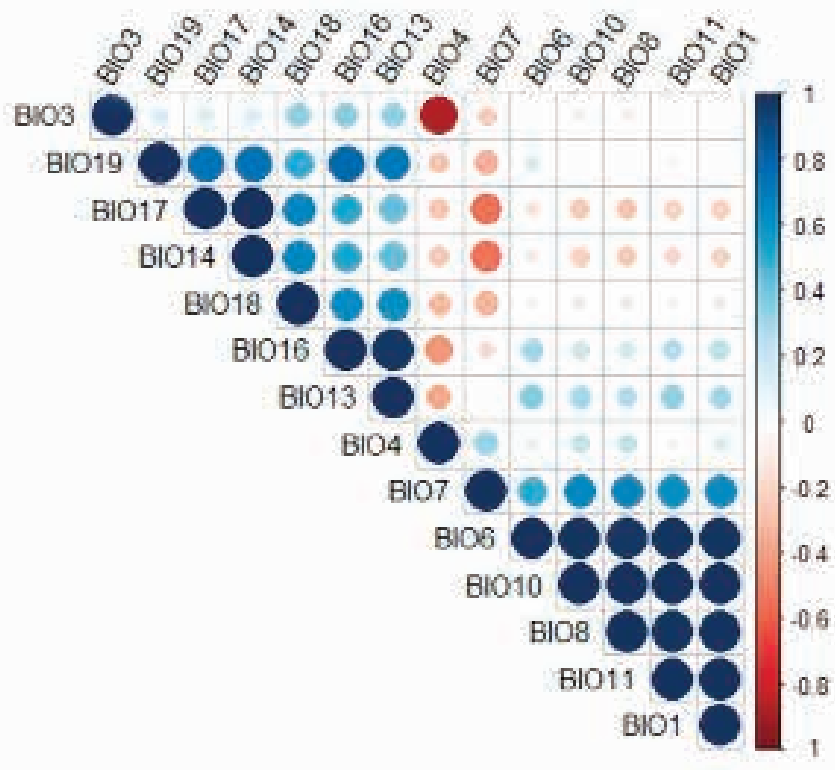

Figure 3. Correlation chart of the bioclimatic variables that make a significant contribution to the predictive model of the distribution of Coendou rufescens. 
the fourth annual quarter (BIO19), and precipitation of the driest month (BIO14) contributed $17.3 \%$.

The area of suitable habitat predicted by the model for $C$. rufescens was $\sim 448.820 \mathrm{~km}^{2}$, which in Colombia spans from the north end of the Eastern Cordillera, crossing the Central and Western Cordillera and Nudo de los Pastos; in Ecuador, this species is distributed in the Andean foothills and moorlands throughout the territory. In Peru, it stretches across the northern and central Andes in Western, Central and Eastern Cordilleras (Figure 4). Colombia has $50.4 \%$ of the suitable distribution of the species, while Peru and Ecuador show $28.5 \%$ and $21.1 \%$, respectively (Table 2 ). The potential distribution of $C$. rufescens in relation to remnant vegetation is reduced in $50.6 \%$ (Table 2, Figure 4), with Peru and Colombia keeping $73 \%$ ( $40.2 \%$ vs $32.8 \%$ ) of remnant vegetation within the potential distribution range of the species (Figure 5). The potential distribution coinciding with the borders of protected areas in the three countries is $14 \%$, with Ecuador and Colombia keeping $10 \%$ (Table 2, Figure 5).

\section{Discussion}

In Ecuador, the distribution range of $C$. rufescens was known by few and scattered records along the Eastern Cordillera, with a single record from the Western Cordillera (Orcés and Albuja 2004; Voss 2015; Vallejo and Boada 2017; Romero et al. 2018). The localities reported in this study broaden the

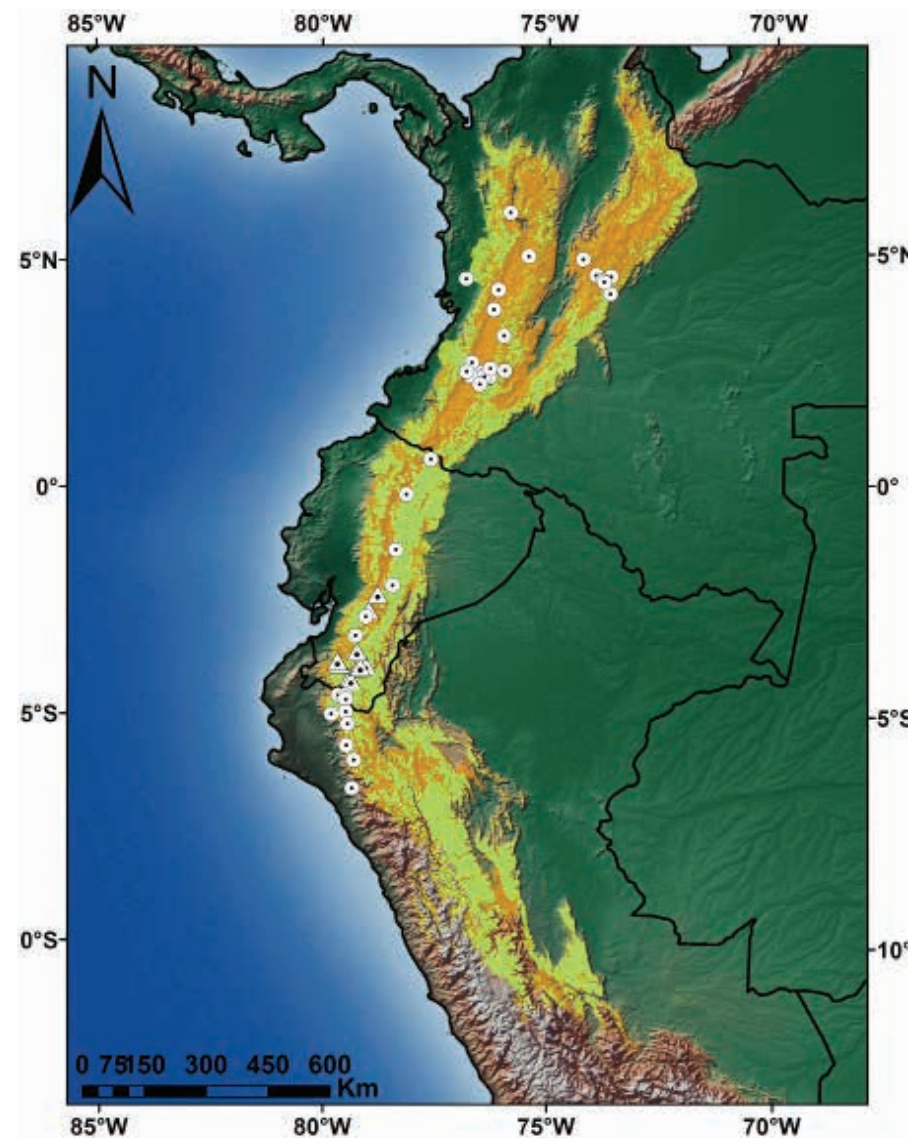

Figure 4. Records and potential distribution of Coendou rufescens (orange), potential range of $C$. rufescens in relation to remnant vegetation in Colombia, Ecuador and Peru (light green). Circles represent records from the literature review; triangles, the new locations reported in this study.
Table 2. Percentage of potential distribution and remnant vegetation of the predictive model for Coendou rufescens.

\begin{tabular}{lrrr} 
Country & $\begin{array}{c}\text { Potential } \\
\text { Distribution km² (\%) }\end{array}$ & $\begin{array}{c}\text { Remnant } \\
\text { vegetation } \mathbf{~ k m}^{\mathbf{2}} \text { (\%) }\end{array}$ & $\begin{array}{c}\text { Potential } \\
\text { distribution within } \\
\text { protected areas (\%) }\end{array}$ \\
\hline Colombia & $226,146(50.4)$ & $72,675(32.7)$ & $21,931(34.9)$ \\
Peru & $128,104(28.5)$ & $89,252(40.2)$ & $18,522(29.5)$ \\
Ecuador & $94,570(21.1)$ & $59,665(26.9)$ & $22,279(35.5)$ \\
Total & $448,820(100)$ & $221,592(100)$ & $62,732(100)$ \\
\hline
\end{tabular}

distribution range of the species to the south and southwest areas of the Eastern and Western Cordillera across an altitudinal range of 1.120-4.387 $\mathrm{m}$. The Camino del Inca locality in the Sangay National Park at 4,387 masl is the highest-elevation record for the species (Appendix 1) and for the family Erethizontidae (Voss 2015; Barthelmess 2016). High elevations are characterized by extreme weather conditions, where only the best-adapted species are able to thrive (Monge and León-Velarde 1991); thus, mammals that inhabit ecosystems above 4,300 m asl are currently scarce in Ecuador (< 10 spp.) (Tirira 2017; Brito et al. 2018).

Observations by the authors and references provided by local residents indicate that $C$. rufescens inhabiting southwest areas move at ground level and climb easily, being tolerant to anthropic areas such as villages and farming land; a similar behavior has been documented for Peruvian (More

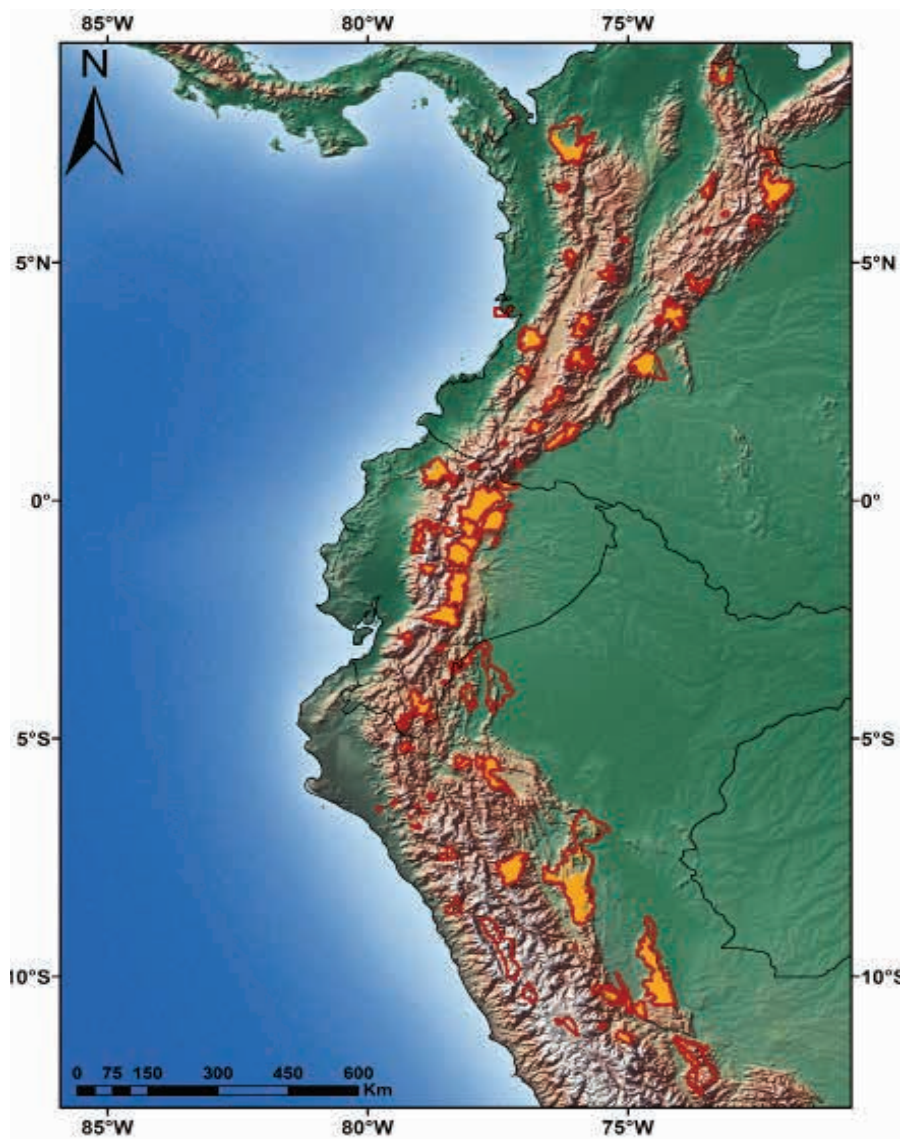

Figure 5. Potential distribution range of Coendou rufescens (orange) in relation to protected areas in Colombia, Ecuador and Peru (red boundaries). 
and Crespo 2016) and Ecuadorian populations (Brito and Ojala-Barbour 2016). Similar to other related species (Voss 2015), the specimens of $C$. rufescens observed in this study showed a quiet temperament and adopted a still position, hiding the head and ruffling up the spines when perceiving danger. In the province of Loja, local peasants frequently capture specimens of $C$. rufescens resting on tree branches to keep them as pets and/or for consumption as bush meat. Rhodas et al. (2007) report this as one of the species most commonly marketed in southern Ecuador.

The distribution of Coendou rufescens predicted by the model yielded a high AUC, and the AUC ratio in the analysis of partial ROC curves showed that the predictive capability of the model is significantly better than the one produced by a random model (Hanley and McNeil 1982; Lobo et al. 2008; Peterson et al. 2008) and may be a similar representation to the distribution range of the species. The results of this study are consistent with the distribution reported elsewhere (Alberico et al. 1999; Orcés and Albuja 2004; Voss 2011; Brito and Ojala-Barbour 2016; More and Crespo 2016; Romero et al. 2018), although the suitable habitat that may be occupied by the stump-tailed porcupine was maximized; thus, the maximum entropy principle allowed us to model the convergence of environmental variables (Phillips et al. 2006) in a total area of $448.820 \mathrm{~km}^{2}$. However, our map predictive model - does not display the actual geographical distribution of the species, as the existence of a suitable habitat is no guarantee that the species indeed inhabits the whole habitat. However, the absence of $C$. rufescens in an area of suitable habitat could be the result of biotic interactions (e. g. competition with other species, presence of predators) or the inability of the species to move across geographical barriers (e. g. rivers, canyons, mountains, etc.) to colonize that habitat.

It is considered that the two bioclimatic variables that made a significant contribution to the predictive distribution model of $C$. rufescens - seasonal temperature (BIO4) and minimum temperature of the coldest month (BIO6) are associated to the habitat occupied by the species (Ministerio del Ambiente del Ecuador 2013; Voss 2015; Brito and Ojala-Barbour 2016; More and Crespo 2016). The relationship between the Andean mountain ranges and these variables is displayed in the case study for small vertebrates; Muñoz-Ortiz et al. (2015) report that the localities of Rheobates (Anura) at the Central Cordillera are related to seasonal temperature (BIO4), whereas the localities at the Eastern Cordillera relate to the minimum temperature of the coldest month (BIO6). Coendou rufescens are distributed along the Western, Central and Eastern Cordillera, which explains a $>80 \%$ contribution by the two variables.

In a number of studies, the maximum entropy model (MaxEnt) has yielded a better performance vs. other species-distribution models (Elith et al. 2006; Phillips et al. 2006; Aguirre-Gutiérrez et al. 2013), and some studies support that the ability of the algorithm to model the predictive distribution of the species is superior to that of other algorithms; however, these authors suggest that consensus models may be used in order to reduce the uncertainty in the predictions of individual models (Marmion et al. 2009; Qiao et al. 2015; Zhu and Peterson 2017). However, irrespective of the model - or a consensus of models - used, caution should be exercised when extrapolating data from the model, as it will depend on the objectives of the research.

Although Colombia is the country with the greatest portion of the potential distribution of the stump-tailed porcupine, when evaluating the proportion related to remnant vegetation, Peru comprises $20 \%$ of the remaining distribution with respect to this variable, being the country with greatest coverage for the species. For its part, Colombia shows highly fragmented habitats in the western, central and eastern foothills (SIAC 2017), similar to Ecuador, which also faces threats related to habitat fragmentation in the Andes (Ministerio del Ambiente del Ecuador 2013; Lozano et al.2006). However, the presence of continuous protected areas in Ecuador - mostly in the eastern slope - may ensure the mid-to-long-term permanence of the species.

Finally, the fact that several of our records correspond to road killed individuals evidences the need to implement measures to reduce the impact of roads on natural populations of this and other wild species, such as the construction of structural crossing tunnels/bridges (at least in the vicinity of National Park), in addition to implementing adequate signaling (Bank et al. 2002; Grillo et al. 2010).

\section{Acknowledgments}

We thank P. Szekely, R. Albuja, I. Pardo, C. Cisneros and P. Tito for providing photographs of porcupine specimens. Thanks also to members of the bachelor's degree of Biology at UTPL, especially C. Cartuche, D. del Pozo and H. Iñiguez for their assistance in field work, and to the Regional District 7 of the Ministry of the Environment. R. Ojala-Barbour, V. Romero, M. Diaz and two anonymous reviewers made valuable comments on the manuscript. María Elena Sánchez-Salazar translated the manuscript into English.

\section{Literature Cited}

Aguirre-Gutiérrez., J., L. G. Carvalheiro, C. Polce, E. E. van Loon, N. Raes, M. Reemer, and J. C. Biesmeijer. 2013. Fit-for-purpose: species distribution model performance depends on evaluation criteria-Dutch hoverflies as a case study. PloS One 8:e63708.

Alberico, M., V. Rojas-Díaz, and J. G. Moreno. 1999. Aporte sobre la taxonomía y distribución de los puercoespines (Rodentia: Erethizontidae) en Colombia. Revista de la Academia Colombiana de Ciencias Exactas, Físicas y Naturales 23:595-612. Albuja, L., A. Almendáriz, R. Barriga, F. Cáceres, L. Montalvo, and J. Román. 2012. Fauna de Vertebrados del Ecuador. Escuela Politécnica Nacional. Quito, Ecuador.

Bank, F. G., C. L. IrWin, G. L. Evink, M. E. Gray, S. Hagood, J. R. Kinar, A. Levy, D. Paulson, B. Ruediger, R. M. Sauvajot, D. J. Scott, and P. WHITE. 2002. Wildlife habitat connectivity across European highways. American Trade Initiatives. Alexandria, U. S. A. 
Barthelmess, E. L. 2016. Family Erethizontidae. Pp. 372-397, in Handbook of Mammals of the World. Vol. 6. Lagomorphs and Rodents: Part 1 (Wilson, D. E., Lacher, T. E., and Mittermeier, R. A, eds.). Lynx, Barcelona, España.

Braunisch, V., K. Bollmann, R. F. Graf, and A. H. Hirzel. 2008. Living on the edge-modeling habitat suitability for species at the edge of their fundamental niche. Ecological Modelling 214:153-167.

Brito, J., ANd R. Ojala Barbour. 2016. Mamíferos no voladores del Parque Nacional Sangay, Ecuador. Papéis Avulsos de Zoologia 56:45-61.

Brito, J., M. A. Camacho, V. Romero, and A. F. Vallejo. 2018. Mamíferos de Ecuador. Museo de Zoología, Pontificia Universidad Católica del Ecuador. Versión 2018.0. https://bioweb.bio/faunaweb/ mammaliaweb/. Consultado el 23 de febrero 2018.

Cerón, C., W. Palacios, R. Valencia, and R. Sierra. 1999. Las formaciones naturales de la Costa del Ecuador. Propuesta preliminar de un sistema de clasificación de vegetación para el Ecuador continental. Proyecto INEFAN/GERF-BIRF y Ecociencia. Quito, Ecuador.

Chatterjee, H. J., J. S. Y. Tse, and S. T. Turvey. 2012. Using ecological niche modelling to predict spatial and temporal distribution patterns in Chinese gibbons: lessons from the present and the past. Folia Primatologica 83: 85-99.

Cuesta, F., M. Peralvo, A. Merino-Viteri, M. Bustamante, F. Baquero, J. F. Freile, and O. Torres-Carvajal. 2017. Priority areas for biodiversity conservation in mainland Ecuador. Neotropical Biodiversity 3:93-106.

Elith, J., C. H. Graham, R. P. Anderson, M. Dudík, S. Ferrier, Guisan, A., R. J. Hijmans, F. Huettmann, J. R. Leathwick, A. Lehmann, J. LI, L. G. Lohmann, B. A. Loiselle, G. Manion, C. Moritz, M. Nakamura, Nakazawa, J. McC. Overton, A. T. Peterson, S. J. Phillips, K. S. Richardson, R. Scachetti-Pereira, R. E. Schapire, J. Sobero'n, S. Williams, M. S. WisZ, and N. E. Zimmermann. 2006. Novel methods improve prediction of species' distributions from occurrence data. Ecography 29:129-151.

Elith, J., S. J. Phillips, T. Hastie, M. Didík, Y. E. Chee, and C. J. Yates. 2011. A statistical explanation of MaxEnt for ecologists. Diversity and Distributions 17:43-57.

EsRI. 2017. ArcGIS Desktop: Release 10 v.5.1 Redlands, CA: Environmental Systems Research Institute.

Fernández de Córdoba-Torres, J., and C. Nivelo. 2016. Guía de mamíferos de las zonas urbana y periurbanas de Cuenca. Gobierno Autónomo Descentralizado Municipal del Cantón Cuenca y Comisión Ambiental Universidad del Azuay. Cuenca, Ecuador.

GraY, J. E. 1865. Notice of an apparently undescribed species of American porcupine. Proceedings of the Zoological Society of London 33:321-322.

Grillo, C, J. A. Bissonette, and P. C. Cramer. 2010. Mitigation Measures to Reduce Impacts on Biodiversity. Pp. 73-114, in Highways: Construction, Management, and Maintenance. (Jones, S. R, ed). Frank Columbus, U. S. A.

HANLEY, J. A., AND B. J. McNeIL. 1982. The meaning and use of the area under a Receiver Operating Characteristic (ROC) curve. Radiology 143:29-36.

Hijmans, R., S., Cameron, J. Parra P. G. Jones, and A. Jarvis. 2005. Very high resolution interpolated climate surfaces for global land areas. International Journal of Climatology 25:1965-1978.
Kerley, G. I. H., R. Kowalczyk, and J. P. G. M. Cromsigt. 2012. Conservation implications of the refugee species concept and the European bison: king of the forest or refugee in a marginal habitat? Ecography 35:519-529.

LACÉPĖDE, B. G. E. DE LA V. 1799. Tableau des divisions, sousdivivisions, orders et genres des Mammifères. Supplement to Discours d'ouverture et de clôture du cours d'histoire naturelle donné dans le Muséum National d'Histoire Naturelle, I'an VII de la République, et tableau méthodiques des mammifères et de oiseaux. Paris, France.

Liu, C., P. M. Berry, T. P. Dawson, and R. G. Pearson. 2005. Selecting thresholds of occurrence in the prediction of species distributions. Ecography 28:385-393.

Lizcaíno, D., D. Prieto-Torres, and M. Ortega-Andrade. 2015. Distribución de la danta de montaña (Tapirus pinchaque) en Colombia: importancia de las áreas no protegidas para la conservación en escenarios de cambio climático. Pp. 115-129, in Conservación de grandes vertebrados en áreas no protegidas de Colombia, Venezuela y Brasil (Payán, E., C. Lasso, and C. Castaño-Uribe, eds.). Serie Editorial Fauna Silvestre Neotropical. Instituto de Investigación de Recursos Biológicos Alexander von Humbolt (IAvH). Bogotá, Colombia. Lobo, J. M., A. Jiménez-Valverde, and R. Real. 2008. AUC: a misleading measure of the performance of predictive distribution models. Global Ecology and Biogeography 17:145-151.

Lozano, P., R. W. Bussmann, And M. Küppers. 2006. Landslides as ecosystem disturbance-their implications and importance in Southern Ecuador. Lyonia 9:75-81.

Marmion, M., M. Parviainen, M. Luoto, R. K. HeikKinen, and W. Thuiller. 2009. Evaluation of consensus methods in predictive species distribution modelling. Diversity and distributions 15:59-69. Menéndez-Guerrero, P., and C. Graham. 2013. Evaluating multiple causes of amphibian declines of Ecuador using geographical quantitative analyses. Ecography 36:001-014.

MINAM. 2017. Ministerio del Ambiente del Perú. http://www. minam.gob.pe/. Fecha de acceso 17 mayo 2017.

Ministerio del Ambiente del Ecuador. 2013. Sistema de clasificación de los ecosistemas del Ecuador continental. Subsecretaría de Patrimonio Natural. Quito, Ecuador.

Monge, C., and F. Leon-Velarde. 1991. Physiological adaptation to high altitude: oxygen transport in mammals and birds. Physiological Reviews 71:1135-1172.

More, A., AND S. CRespo. 2016. Documented records of the stump-tailed porcupine Coendou rufescens (Erethizontidae, Rodentia) in northwestern Peru. The Biologist 14:359-369.

Morueta-Holme, N., C. FløjgaARd, and J. C. Svenning. 2010. Climate change risks and conservation implications for a threatened small-range mammal species. PloS One 5: e10360.

Muñoz-Ortiz, A., Á. A. Velásquez-Álvarez, C. E. Guarnizo, and A. J. CRAwford. 2015. Of peaks and valleys: testing the roles of orogeny and habitat heterogeneity in driving allopatry in mid-elevation frogs (Aromobatidae: Rheobates) of the northern Andes. Journal of Biogeography 42:193-205.

NüChel, J., P. K. BøCher, W. XIAO, A. X. ZhU, AND J. C. SVenning. 2018. Snub-nosed monkeys (Rhinopithecus): potential distribution and its implication for conservation. Biodiversity and Conservation 1-22. 
Orcés, G., And L. Albuja. 2004. Presencia de Speothos venaticus (Carnivora: Canidae) en el Ecuador occidental y nuevo registro de Coendou rufescens (Rodentia: Erethizontidae) en el Ecuador. Politécnica 25, Biología 5:11-18.

Ortega-Andrade, H. M, D. A, Prieto-Torres, I. Gómez-Lora, and D. J. LizCANo. 2015. Ecological and Geographical Analysis of the Distribution of the Mountain Tapir (Tapirus pinchaque) en Ecuador: Importance of Protected Areas in Future Scenarios of Global Warming. PLoS ONE 10:e0121137.

Osorio-Olvera, L. 2018. Niche Toolbox. http://shiny.conabio. gob.mx:3838/nichetoolb2/. Consultado el 23 de noviembre 2017.

Peterson A.T, M. Papeş, And J. Soberón. 2008. Rethinking receiver operating characteristic analysis applications in ecological niche modeling. Ecological Modelling 213: 63-72.

Peterson, A. T, J. Soberón, R. G. Pearson, R. P. Anderson, E. MartínezMeyer, M. Nakamura, and M. B. Aráujo. 2011. Ecological niches and geographic distributions (MPB-49). Princeton University Press.

PhILLIPS, S. J, AND M. Dudík. 2008. Modeling of species distributions with Maxent: new extensions and a comprehensive evaluate on. Ecography 31:161-175.

Phillips, S, R. P. Anderson, and R, E. Schapire. 2006. Maximum entropy modelling of species geographic distributions. Ecological Modelling 190:231-259.

Qiao, H., J. Soberón, and A. T. Peterson. 2015. No silver bullets in correlative ecological niche modelling: insights from testing among many potential algorithms for niche estimation. Methods in Ecology and Evolution 6:1126-1136.

R CORE TEAM. 2016. R: A language and environment for statistical computing. $\mathrm{R}$ foundation for Statistical Computing, Vienna, Austria. http://www.R-project.org/.

Ramírez-Chaves, H. E., W. Pérez, and J. Ramírez-Mosquera. 2008. Mamíferos presentes en el municipio de Popayán, CaucaColombia. Boletín Científico Centro de Museos. Museo de Historia Natural 12:65-89.

Ramírez-Chaves, H. E., A. F. Suárez-Castro, D. M. Morales-Martínez, and M. C. Vallejo-Pareja. 2016. Richness and distribution of porcupines (Erethizontidae: Coendou) from Colombia. Mammalia 80:181-191.

Renner, I. W., AND D. I. Warton. 2013. Equivalence of MAXENT and Poisson Point Process Models for Species Distribution Modeling in Ecology. Biometrics 69:274-281.

Reyes-Puig, C., C. Almendáriz, and O.Torres-Carvajal. 2017. Diversity, threat, and conservation of reptiles from continental Ecuador. Amphibian and Reptile Conservation 11:51-58.

Rodas, L. F., F. Sánchez, L. Cuenca, and J. Manzanilla. 2007. Manual de Procedimientos contra el Tráfico llegal de Fauna en el Ecuador. Naturaleza and Cultura Internacional, DarwinNet y Ministerio del Ambiente. Loja, Ecuador.

Romero, V., C. Racines-Márquez, And J. Brito. 2018. A short review and worldwide list of wild albino rodents with the first report of albinism in Coendou rufescens (Rodentia: Erethizontidae). Mammalia 82: DOI:10.1515/mammalia-2017-0111

Sánchez, F., B. Gómez-valencia, S. J. Álvarez, and M. Gómez-laverde. 2008. Primeros datos sobre los hábitos alimentarios del tigrillo, Leopardus pardalis, en un bosque andino de Colombia. Revista UDCA Actualidad y Divulgación Científica 11:101-107.
SIAC. 2017. Sistema de Información ambiental de Colombia. www.siac.gov.co/. Consultado el 14 mayo 2017.

SIN. 2017. Sistema Nacional de Información. http://sni.gob. ec/. Consultado el 14 mayo 2017.

TIRIRA, D., AND C. BoAdA. 2009. Diversidad de mamíferos en bosques de Ceja Andina alta del nororiente de la provincia de Carchi, Ecuador. Boletín Técnico 8, Ecuador Serie Zoológica 4-5:1-24.

TIRIRA, D. 2016. Coendou rufescens. The IUCN Red List of Threatened Species. Version 2016. http://www.iucnredlist. org/details/7010/0. Consultado el 20 agosto 2017.

TIRIRA, D. 2017. Guía de campo de los mamíferos del Ecuador. Ediciones Murciélago Blanco. Quito, Ecuador.

Valencia, R., C. Cerón, and W. Palacios. 1999. Las formaciones naturales de la Sierra del Ecuador. Propuesta preliminar de un sistema de clasificación de vegetación para el ecuador continental. Proyecto INEFAN/GEF-BIRF y EcoCiencia. Quito, Ecuador.

Vallejo, A. F., and C. Boada. 2017. Coendou rufescens. In, Mamíferos de Ecuador. (Brito, J., M. A. Camacho, and V. Romero. eds). Versión 2017.0. Museo de Zoología, Pontificia Universidad Católica del Ecuador. Quito, Ecuador. https:// www.bioweb.bio/faunaweb/mammaliaweb/FichaEspecie/ Coendou\%20rufescens. Consultado el 20 de agosto 2017.

Voss, R. S. 2011. Revisionary Notes on Neotropical Porcupines (Rodentia: Erethizontidae). An annotated Checklist of the species of Coendou Lacépède, 1799. American Museum Novitates 20:1-36.

Voss, R. S. 2015. Family Erethizontidae Bonaparte, 1845. Pp. 786-805, in Mammals of South America, Volume 2: Rodents. (Patton, J. L., U. F. J. Pardiñas, and G. D'Elía, eds.). The University of Chicago Press. Chicago, U. S. A.

Voss, R. S., C. Hubbard, and S. A. Jansa. 2013. Phylogenetic relationships of New World porcupines (Rodentia, Erethizontidae): implications for taxonomy, morphological evolution, and biogeography. American Museum Novitates 3769:1-36.

Williams, R. 2008. Mamíferos de Chaparrí. Pp. 78-85, in Guía de la vida silvestre de Chaparrí. (Plenge, H.,and R. Williams, eds.). Geográfica EIRL. Lima, Perú.

Zhu, G. P., and A. T. Peterson. 2017. Do consensus models outperform individual models? Transferability evaluations of diverse modeling approaches for an invasive moth. Biological Invasions 19:2519-2532.

Associated editor: Monica Díaz

Submitted: December 29, 2017; Reviewed: January 31, 2018;

Accepted:March 19, 2018; Published on line:April 30, 2018. 
Appendix 1.

Localities of records of Coendou rufescens throughout its distribution range.

\begin{tabular}{|c|c|c|c|c|c|}
\hline Country/ Department/ Province & Locality & Latitude & Longitude & Altitude & Reference \\
\hline \multicolumn{6}{|c|}{ Colombia } \\
\hline Antioquía & Concordia & 6.0333 & -75.9000 & - & Ramírez-Chaves et al. (2016) \\
\hline Caldas & Manizales & 5.0666 & -75.5166 & - & Ramírez-Chaves et al. (2016) \\
\hline Cundinamarca & La Vega & 4.9833 & -74.3333 & - & Ramírez-Chaves et al. (2016) \\
\hline Cundinamarca & La Aguadita & 4.6333 & -74.0500 & - & Ramírez-Chaves et al. (2016) \\
\hline Cundinamarca & Chingaza & 4.6000 & -73.7333 & - & Ramírez-Chaves et al. (2016) \\
\hline Cundinamarca & Choachí & 4.5166 & -73.9166 & - & Ramírez-Chaves et al. (2016) \\
\hline Cundinamarca & Fómeque & 4.4833 & -73.8833 & - & Ramírez-Chaves et al. (2016) \\
\hline Cundinamarca & Quétame, quebrada Susumuco & 4.2166 & -73.7500 & 800 & Gray (1865) \\
\hline Meta & Puerto López & 4.0833 & -72.9500 & - & Ramírez-Chaves et al. (2016) \\
\hline Cauca & San Antonio & 4.5833 & -76.8833 & - & Ramírez-Chaves et al. (2016) \\
\hline Cauca & Bolívar & 4.3333 & -76.1833 & - & Ramírez-Chaves et al. (2016) \\
\hline Cauca & Buga & 3.9000 & -76.2833 & - & Ramírez-Chaves et al. (2016) \\
\hline Cauca & Hato Viejo Natural Reserve & 3.3166 & -76.0666 & - & Ramírez-Chaves et al. (2016) \\
\hline Cauca & Munchique & 2.7333 & -76.7666 & - & Ramírez-Chaves et al. (2016) \\
\hline Cauca & Charguayaco & 2.4333 & -76.8000 & - & Ramírez-Chaves et al. (2016) \\
\hline Cauca & Sabanetas & 2.5333 & -76.8833 & - & Ramírez-Chaves et al. (2016) \\
\hline Cauca & Silvia & 2.6000 & -76.3666 & 2,040 & Ramírez-Chaves et al. (2016) \\
\hline Cauca & Road to Inzá & 2.5500 & -76.0500 & - & Ramírez-Chaves et al. (2016) \\
\hline Cauca & Road to Sotará & 2.2500 & -76.6000 & - & Ramírez-Chaves et al. (2016) \\
\hline Cauca & Vereda Las Guacas & 2.5000 & -76.5833 & 1,800 & Ramírez-Chaves et al. (2016) \\
\hline Cauca & Vereda Clarete & 2.5166 & -76.5333 & - & Alberico et al. (1999) \\
\hline Cauca & $\begin{array}{l}\text { Vereda Aguas Claras, Quebrada La } \\
\text { Parada, La Tupía }\end{array}$ & 2.4000 & -76.4166 & 2,590 & Ramírez-Chaves et al. (2008) \\
\hline Cauca & Vereda Santa Teresa & 2.4166 & -76.3833 & 3,535 & Ramírez-Chaves et al. (2008) \\
\hline Cauca & Vereda Santa Bárbara & 2.3833 & -76.5500 & 1,900 & Ramírez-Chaves et al. (2008) \\
\hline Cauca & Vereda Julumito, Río Saté & 2.4500 & -76.6500 & 1,700 & Ramírez-Chaves et al. (2008) \\
\hline Cauca & Vereda Pisojé & 2.4166 & -76.5000 & 1,800 & Ramírez-Chaves et al. (2008) \\
\hline \multicolumn{6}{|c|}{ Ecuador } \\
\hline Carchi & RB Guandera & -0.6000 & -77.6666 & $3,405-3,405$ & Tirira and Boada (2009) \\
\hline Imbabura & Pimampiro & -0.1768 & -78.1940 & 2,900 & Romero et al. (2018) \\
\hline Morona Santiago & Sangay National Park & -2.1917 & -78.4974 & 3,650 & Brito and Ojala-Barbour (2016) \\
\hline Morona Santiago & Sangay National Park & -2.3889 & -78.3016 & 2,500 & Brito and Ojala-Barbour (2016) \\
\hline Tungurahua & Baños & -1.3956 & -78.4249 & 1,855 & Voss (2015) \\
\hline Chimborazo & Camino del Inca & -2.3894 & -78.8193 & 4,387 & This study \\
\hline Azuay & Balcón del Azuay & -2.8830 & -79.0797 & 2,800 & Fernandez de Cordoba-Torres and Nivelo (2016) \\
\hline Azuay & ElTuni & -2.7520 & -79.0110 & 3,200 & MEPN 10433 Este Estudio \\
\hline Zamora Chinchipe & Estación San Francisco & -3.9675 & -79.0741 & 1,900 & MEPN 3260 Este Estudio \\
\hline Azuay & Valle de Yunguilla & -3.3000 & -79.3000 & 1,650 & Voss (2015) \\
\hline Loja & Vicinity of Gonzanama & -4.2349 & -79.4300 & 2,092 & This study \\
\hline Loja & Olmedo & -3.9354 & -79.6464 & 1,284 & This study \\
\hline Loja & Vicinity of the Villonaco Wind Project & -4.0139 & -79.2439 & 2,401 & This study \\
\hline Loja & Quilanga & -4.2972 & -79.4011 & 1,897 & This study \\
\hline Loja & Chaguarpamba & -3.8720 & -79.6938 & 1,120 & This study \\
\hline Loja & Barrio Zamora Huayco & -4.0058 & -79.1845 & 2,195 & This study \\
\hline Loja & $5 \mathrm{~km}$ from Saraguro & -3.6615 & -79.2688 & 2,938 & This study \\
\hline \multicolumn{6}{|c|}{ Perú } \\
\hline Chongoyape & RE Chaparrí & -6.6784 & -79.3788 & - & Williams (2008) \\
\hline
\end{tabular}


Continue...

\begin{tabular}{|c|c|c|c|c|c|}
\hline Piura & Socchabamba & -4.6158 & -79.6786 & 2,485 & More and Crespo (2016) \\
\hline Piura & Samanguilla & -4.6250 & -79.5191 & 2,335 & More and Crespo (2016) \\
\hline Piura & Toronche & -4.7114 & -79.5877 & $2,269-2,308$ & More and Crespo (2016) \\
\hline Piura & Totora & -4.9852 & -79.5152 & 2,570 & More and Crespo (2016) \\
\hline Piura & Ñoma & -5.0344 & -79.8311 & 1,715 & More and Crespo (2016) \\
\hline Piura & Santa Rosa de Congona & -5.2538 & -79.4747 & 2,490 & More and Crespo (2016) \\
\hline Piura & San Juan de Palomataz & -5.7300 & -79.5022 & 2,700 & More and Crespo (2016) \\
\hline Kañaris-Lambayeque & Congoña & -6.0541 & -79.3355 & 2,800 & More and Crespo (2016) \\
\hline
\end{tabular}

